\title{
DIFFERENCES BETWEEN FAT-RELATED CHARACTERISTICS OF SOUR CREAM AND SOUR CREAM ANALOGUES
}

\author{
T. IZsóa ${ }^{\mathrm{a}}$ Gy. KASZA ${ }^{\mathrm{a} *}$ and L. SOMOGYI ${ }^{\mathrm{b}}$ \\ ${ }^{a}$ Directorate of Risk Management, National Food Chain Safety Office, H-1024 Budapest, Kitaibel Pál utca 1. \\ Hungary \\ ${ }^{b}$ Department of Grain and Industrial Plant Processing, Faculty of Food Science, Szent István University, \\ H-1118 Budapest, Villányi út 29-43. Hungary
}

(Received: 20 February 2020; accepted: 30 June 2020)

\begin{abstract}
Modification of dairy products' fat composition or replacement by other fats are common practices in the industry. Products in which milkfat is partially or wholly substituted by vegetable fats are defined as dairy analogues. This study delivers gap-filling information about sour cream analogues in nutritional aspects, focusing on the fat-related attributes. Analogue sour creams contained $29.6 \%$ less saturated fatty acids, $88.4 \%$ less cholesterol and $88.7 \%$ more mono- and poly-unsaturated fatty acids than the sour creams. Trans fatty acids were present in both products, which could not be linked to artificial hydrogenation in either case. Digestibility of the examined samples might be different, as sour creams had more short and medium chain fatty acids than the analogues. Overall, sour cream analogues, besides serving as an alternative to sour cream, have particular advantages based on their nutritional values.
\end{abstract}

Keywords: dairy analogue, sour cream analogue, palm fat, milkfat, fatty acids, cholesterol

Consumption of dairy products causes difficulties for a significant part of the society because of their allergen, lactose, and cholesterol content and/or these products are not affordable for some due to their price (KRUPA et al., 2011). Furthermore, in the last few decades, the perception of milk's and dairy products' nutritional benefits declined as milkfat consumption was associated with atherosclerosis and heart diseases (EBRINGER et al., 2008).

Between the 1940s and 1990s, dietary cholesterol (and also saturated fatty acid intake) was considered as one of the main causes of cardiovascular diseases, which lead to the excessive promotion of lipid-lowering dietary recommendations (MCNAMARA, 2014). Nutritionists argue that instead of avoiding cholesterol, we should focus on maintaining the balance of absorbed and synthesised amounts, also, several studies have shown that dietary cholesterol does not significantly increase the risk of heart conditions in case of healthy individuals (Fernandez, 2012; MCNAMARA, 2014). A minor part of the population indeed needs to reduce its intake, but the majority will unnecessarily deprive themselves of a highquality protein source such dairy products (FERNANDEZ, 2012).

A recent study revealed that the two most important attributes of dairy products for consumers are low fat content and being cholesterol-free (PINTo et al., 2016), which suggest that the public is still extremely interested by fats used in these commodities.

Reduction of milkfat content, modification of milk's and dairy products' fat composition, or replacement by other fats are common practices in the industry. Products in which milkfat is partially or wholly substituted by vegetable fats are defined as dairy analogues (FAO/WHO

\footnotetext{
* To whom correspondence should be addressed.

Phone: +36 20/ 4548 418; e-mail: kaszagy@nebih.gov.hu.
} 
Food Standards, 2019). Ingredients of plant origin used in these products are cheaper; therefore, the main reason for dairy analogue production is cost-effectiveness.

Traditional sour cream is made from only two ingredients, cream and bacterial cultures: the acidification is done by lactic acid bacteria that also provide the distinctive taste and texture of sour cream (SzAKÁLY, 2001). One type of sour cream analogues is usually made from skimmed milk mixed with vegetable fat and acidified by the bacterial culture, which is the most common practice among Hungarian manufacturers. In other countries, beside milkderived components, producers usually add water and food additives. There are also sour cream analogues that are made exclusively from vegetable sources (HAISMAN, 2011; NOZNICK et al. 2015).

Substitution of highly valuable milkfat with vegetable fats affects not only the price of the product, but technological aspects should be considered, too. Milkfat has a complex fatty acid composition, which eventuate a nearly inimitable melting profile; however, producers handle suitable melting characteristics as a primary selection criterion in regard of vegetable fats and use most frequently palm fat or coconut oil in dairy analogues (HAISMAN, 2011).

Similarly to milkfat (and generally dairy products), palm fat and other so-called tropical oils were linked to the risk of coronary heart disease (CHD) in the 1980s, which triggered campaigns that highlighted saturated fat (SAFA) content and demanded all palm fat to be removed from food products (MCNAMARA, 2010). The need for an appropriately stable fat could only met by partial hydrogenation of vegetable oils, which in turn contained trans fatty acids. Industrially produced trans fatty acids were proved to greatly contribute to the emergence of CHD, and several countries limited its intake, in parallel, public awareness of the risk became high (MCNAMARA, 2010; DAWCZYNSKI \& LORKOWSKI, 2016).

In the case of trans fats, it should be noted that milkfat naturally contains trans fatty acids produced by microbes in the animal's rumen. While there are several studies that confirm the negative health effects of industrial trans fats (iTFA), the harmfulness of ruminant trans fatty acids (rTFA) is still disputed. Nevertheless, if rTFAs had been able to cause the same changes in human serum lipids, possibly their dietary intake would not exceed a level that is considered to be concerning (DAWCZYNSKI \& LORKOWSKI, 2016).

As a conclusion of the above, a lot of questions are raised when discussing which is better: dairy products that naturally contain milkfat or the analogues with substitute palm fat. The results of this comparison will give a clearer picture about advantages and disadvantages of dairy analogues.

\section{Materials and methods}

For the analysis, products of three different Hungarian dairy producers (coded as A, B, and C) - having a selection in both product lines - were chosen: one traditional sour cream and one sour cream analogue from each, with $20 \%$ fat content. Table 1 presents the lists of ingredients of the products. Products were purchased from a local food store in Budapest, Hungary, during April of 2018. Samples were prepared in duplicate for each examination.

The analytical examinations were carried out in the accredited laboratory of the Hungarian National Food Chain Safety Office (NFCSO), National Reference Laboratory of Food and Feed Safety Directorate, using accredited standard methods. 
Table 1. Components of the sour cream and sour cream analogue products from three different producers $(\mathrm{A}, \mathrm{B}$, and $\mathrm{C})$ as indicated on the label

\begin{tabular}{lllll}
\hline Product & Milk base & Fat source & $\begin{array}{l}\text { Lactic acid bacteria } \\
\text { source }\end{array}$ & Other components \\
\hline Sour cream A & Cream & Milkfat & Culture & None \\
Sour cream analogue A & Skimmed milk & Palm fat & Culture & None \\
Sour cream B & Homogenised cream & Milkfat & Pure culture & None \\
Sour cream analogue B & Skimmed milk & Palm fat & Pure culture & Milk protein concentrate \\
Sour cream C & Cream & Milkfat & Culture & None \\
Sour cream analogue C & Milk & Palm fat & Pure culture & None \\
\hline
\end{tabular}

The protein content of the products was determined based on the nitrogen content by Kjeldahl method (MSZ 1385:1987). Amount of lactose was measured by high-performance liquid chromatography based on the work of DuNMIRE and ОтTо (1979), which was carried out after sample clarification by separation of interfering compounds adding Carrez reagents. Samples' fat content was tested based on the Röse-Gottlieb method (MSZ 9602:1984 Chapter 1). Lactic acid bacteria number was examined on de Man, Rogosa and Sharpe agar by culturing at $30{ }^{\circ} \mathrm{C}$ (ISO 15214:2005). Fatty acid composition (including the amount of SAFA, MUFA, PUFA, omega-3 and -6 fatty acids) (ISO 5508:1992), trans fatty acids (EN ISO 15304:2002), as well as cholesterol content (EN ISO 12228-1:2014) were analysed using various gas chromatographic methods. Sample preparation for fatty acid composition analysis and trans fatty acid content determination were based on the formulation of fatty acid methyl esters (EN ISO 5509: 2000 Chapter 5). Cholesterol content measurement was preceded by a saponification step and purification of desmethyl sterol fraction on a thin layer plate. Parameters of the chromatographic methods are shown in Table 2.

Table 2. Details of the used gas and high-performance liquid chromatographic methods

\begin{tabular}{|c|c|c|c|c|}
\hline Attribute & Lactose content & $\begin{array}{l}\text { Fatty acid } \\
\text { composition }\end{array}$ & $\begin{array}{l}\text { Trans fatty acid } \\
\text { content }\end{array}$ & Cholesterol content \\
\hline Method & HPLC-RI & GC-FID & GC-FID & GC-FID \\
\hline Stationary phase & $\begin{array}{l}\text { Amino-modified } \\
\text { silica-gel }\end{array}$ & $\begin{array}{l}\text { Polar, cross-linked } \\
\text { polyethylene glycol }\end{array}$ & $\begin{array}{l}\text { Polar, cyanopropyl } \\
\text { polysiloxane }\end{array}$ & $\begin{array}{l}\text { Non-polar, 5\% phenyl, } \\
95 \% \text { dimethyl- } \\
\text { polysiloxane }\end{array}$ \\
\hline $\begin{array}{l}\text { Name of the } \\
\text { column }\end{array}$ & $\begin{array}{l}\text { Kromasil } 100 \mathrm{NH}_{2} \\
1005 \mu \mathrm{m}\end{array}$ & FAMEWAX & CP-Sil 88 & CP-Sil 8 CB \\
\hline $\begin{array}{l}\text { Dimensions of the } \\
\text { column }\end{array}$ & $\begin{array}{l}250 \mathrm{~mm} \mathrm{x} \\
4.6 \mathrm{~mm}\end{array}$ & $\begin{array}{l}30 \mathrm{~m} \times 0.25 \mathrm{~mm} \times \\
0.25 \mu \mathrm{m}\end{array}$ & $\begin{array}{l}100 \mathrm{~m} \times 0.25 \mathrm{~mm} \times \\
0.2 \mu \mathrm{m}\end{array}$ & $\begin{array}{l}50 \mathrm{~m} \times 0.25 \mathrm{~mm} \times \\
0.25 \mu \mathrm{m}\end{array}$ \\
\hline $\begin{array}{l}\text { Injector type, } \\
\text { volume }\end{array}$ & $\begin{array}{l}\text { Automatic; } \\
20 \mu 1\end{array}$ & $\begin{array}{l}\text { Multi-mode; } \\
1 \mu \mathrm{l}\end{array}$ & $\begin{array}{l}\text { Universal; } \\
1 \mu 1\end{array}$ & $\begin{array}{l}\text { Programmable } \\
\text { temperature; } \\
1 \mu \mathrm{l}\end{array}$ \\
\hline $\begin{array}{l}\text { Injection } \\
\text { temperature }\end{array}$ & $40^{\circ} \mathrm{C}$ & $250^{\circ} \mathrm{C}$ & $250{ }^{\circ} \mathrm{C}$ & $320^{\circ} \mathrm{C}$ \\
\hline $\begin{array}{l}\text { Type / composition } \\
\text { of mobile phase }\end{array}$ & $\begin{array}{l}\text { Acetonitrile-water } \\
(72: 28)\end{array}$ & $\mathrm{H}_{2}$ & $\mathrm{~N}_{2}$ & $\mathrm{He}$ \\
\hline Flow rate & $1.4 \mathrm{ml} \mathrm{min}-1$ & $1.7 \mathrm{ml} \mathrm{min}^{-1}$ & $0.5 \mathrm{ml} \mathrm{min}-1$ & $1 \mathrm{ml} \mathrm{min}^{-1}$ \\
\hline Detector type & Refractive index & Flame ionisation & Flame ionisation & Flame ionisation \\
\hline $\begin{array}{l}\text { Temperature of the } \\
\text { detector }\end{array}$ & $30^{\circ} \mathrm{C}$ & $250^{\circ} \mathrm{C}$ & $250^{\circ} \mathrm{C}$ & $320^{\circ} \mathrm{C}$ \\
\hline
\end{tabular}

Acta Alimentaria 49, 2020 
Significance of the differences between the results of sour creams and sour cream analogues were analysed by one-way ANOVA (Analysis of Variance), which analysis was carried out using the IBM SPSS 23.0 statistical software (IBM CORP, 2015). The confidence level was set to $95 \%$.

\section{Results and discussion}

Proteins and carbohydrates remain dissolved in the serum phase of the skimmed milk after milkfat separation, as well as water-soluble vitamins and a notable amount of the minerals (EBRINGER et al., 2008), therefore the examined sour cream analogues should contain nearly the same amount of these nutrients if the effectiveness of the fat separation method used by the producer is appropriate. This has been verified by our results as the amounts of protein, fat, and lactose (the carbohydrate content of milk is almost completely derived from lactose) did not differ significantly $\left(\mathrm{F}_{\text {protein }}=4.55, \mathrm{p}_{\text {protein }}=0.10 ; \mathrm{F}_{\text {fat }}=3.06, \mathrm{p}_{\text {fat }}=0.16 ; \mathrm{F}_{\text {lactose }}=1.00\right.$, $\mathrm{p}_{\text {lactose }}=0.37$ ) among the two product categories (Table 3 ). Fat content of the analysed products was compliant to the requirements (CODEX Alimentarius Hungaricus, 2014). This also applies to the lactic acid bacteria content (Table 3), in which no statistically confirmed difference was observed $(\mathrm{F}=0.76, \mathrm{p}=0.43)$.

Table 3. Macronutrients and number of lactic acid bacteria in sour cream and sour cream analogues $(\mathrm{N}=12)$

\begin{tabular}{|c|c|c|c|c|}
\hline \multirow[t]{2}{*}{ General attributes } & \multicolumn{2}{|c|}{ Sour cream } & \multicolumn{2}{|c|}{ Sour cream analogue } \\
\hline & Mean & $\begin{array}{r}\text { Standard } \\
\text { deviation }\end{array}$ & Mean & $\begin{array}{l}\text { Standard } \\
\text { deviation }\end{array}$ \\
\hline Protein $(g / 100 \mathrm{~g})$ & 2.75 & 0.03 & 2.62 & 0.10 \\
\hline Lactose $(\mathrm{g} / 100 \mathrm{~g})$ & 3.1 & 0 & 3.1 & 0.1 \\
\hline Fat $(g / 100 \mathrm{~g})$ & 19.7 & 0.4 & 20.3 & 0.5 \\
\hline Lactic acid bacteria (CFU/g) & $1.1^{*} 10^{\wedge} 7$ & $0.1^{*} 10^{\wedge} 7$ & $1.3 * 10^{\wedge} 7$ & $0.1^{*} 10^{\wedge} 7$ \\
\hline
\end{tabular}

The amount of each fatty acid identified in the samples is detailed in Table 4 . The results of sour creams highlight the complex fatty acid composition of milkfat, while sour cream analogues contain a less versatile set of fatty acids (in accordance with the composition of palm fat). Because a small amount of milkfat remains in the skimmed milk base, some fatty acids (C4-C14 and C19-C24 chain length) rather characteristic of milkfat than palm fat are present in the analogues.

The results of the analysis of fat-related characteristics are shown in Table 5. As expected from the main attributes of milkfat and palm fat, the difference between the quantity of SAFA $(\mathrm{F}=1258.95, \mathrm{P}<0.001)$, MUFA $(\mathrm{F}=522.27, \mathrm{P}<0.001)$, PUFA $(\mathrm{F}=913.59, \mathrm{P}<0.001)$, omega-3 $(\mathrm{F}=12.39, \mathrm{P}=0.024)$, omega-6 $(\mathrm{F}=982.40, \mathrm{P}<0.001)$, trans $(\mathrm{F}=50.84, \mathrm{p}=0.002)$, short chain $(\mathrm{F}=680.84, \mathrm{P}<0.001)$, medium chain $(\mathrm{F}=877.45, \mathrm{P}<0.001)$, and long chain $(\mathrm{F}=238.65$, $\mathrm{P}<0.001)$ fatty acids, and the amount of cholesterol $(\mathrm{F}=709.78, \mathrm{P}<0.001)$ is significant in sour creams and sour cream analogues. 
Table 4. Fatty acid composition of sour cream and sour cream analogue samples $(\mathrm{N}=12)$

\begin{tabular}{|c|c|c|c|c|}
\hline \multirow[t]{2}{*}{ Fatty acids } & \multicolumn{2}{|c|}{ Sour creams } & \multicolumn{2}{|c|}{ Sour cream analogues } \\
\hline & Mean (\%) & Standard deviation $(\%)$ & Mean $(\%)$ & Standard deviation $(\%)$ \\
\hline $\mathrm{C} 4: 0$ & 3.69 & 0.25 & 0.08 & 0.04 \\
\hline C6:0 & 2.50 & 0.14 & 0.12 & 0.03 \\
\hline $\mathrm{C} 8: 0$ & 1.37 & 0.09 & 0.07 & 0.01 \\
\hline C10:0 & 2.89 & 0.16 & 0.10 & 0.04 \\
\hline $\mathrm{C} 11: 0$ & 0.34 & 0.04 & n.d. & - \\
\hline $\mathrm{C} 12: 0$ & 3.58 & 0.16 & 0.30 & 0.06 \\
\hline $\mathrm{C} 13: 0$ & 0.12 & 0.02 & 0.06 & 0.01 \\
\hline $\mathrm{C} 14: 0$ & 11.63 & 0.34 & 1.22 & 0.16 \\
\hline C14:1 & 1.03 & 0.06 & n.d. & - \\
\hline C15:0 & 1.21 & 0.09 & 0.07 & 0.02 \\
\hline C16:0 & 32.57 & 0.89 & 42.16 & 0.24 \\
\hline C16:1 & 2.09 & 0.21 & 0.20 & 0.02 \\
\hline C17:0 & 0.52 & 0.02 & 0.11 & 0.01 \\
\hline C18:0 & 9.47 & 0.22 & 4.80 & 0.16 \\
\hline C18:1 & 20.45 & 0.89 & 39.28 & 0.86 \\
\hline $\mathrm{C} 18: 2$ & 1.97 & 0.30 & 9.31 & 0.26 \\
\hline C18:3 & 0.4 & 0.09 & 0.21 & 0.03 \\
\hline C19:0 & 0.10 & 0.01 & n.d. & - \\
\hline C20:0 & 0.13 & 0.02 & 0.44 & 0.14 \\
\hline C20:5 & 0.07 & 0.01 & n.d. & - \\
\hline $\mathrm{C} 20: 3$ & 0.09 & 0.02 & n.d. & - \\
\hline C20:4 & 0.14 & 0.03 & n.d. & - \\
\hline C20:1 & 0.06 & 0.01 & 0.12 & 0.01 \\
\hline $\mathrm{C} 22: 0$ & n.d. & - & 0.06 & 0.01 \\
\hline $\mathrm{C} 22: 5$ & 0.10 & 0.01 & n.d. & - \\
\hline C24:0 & 0.07 & 0.01 & 0.07 & 0.01 \\
\hline C24:1 & 0.07 & 0.01 & n.d. & - \\
\hline Other & 3.35 & - & 1.22 & - \\
\hline
\end{tabular}

n.d.: not detectable

As it is shown in Table 5, saturated fatty acids are dominant in sour cream, while in the analogue products the ratio of saturated and unsaturated fatty acids is more balanced. Saturated fatty acids are less efficiently absorbed, moreover, they increase the risk of CHD and CVD (cardiovascular diseases) more than unsaturated fatty acids (RAMíREZ et al., 2001). In addition, they contribute to the development of obesity and metabolic syndromes (EBRINGER et al., 2008). The effort to mitigate saturated fatty acid intake is an official recommendation of WHO (World Health Organization) (WHO, 2018), for which dairy analogues may be suitable. 
Table 5. Fat-related differences between sour cream and sour cream analogue $(\mathrm{N}=12)$

\begin{tabular}{|c|c|c|c|c|}
\hline \multirow[t]{2}{*}{ Fat-related attributes } & \multicolumn{2}{|c|}{ Sour cream } & \multicolumn{2}{|c|}{ Sour cream analogue } \\
\hline & Mean & $\begin{array}{l}\text { Standard } \\
\text { deviation }\end{array}$ & Mean & $\begin{array}{l}\text { Standard } \\
\text { deviation }\end{array}$ \\
\hline Total of SAFA $(\mathrm{g} / 100 \mathrm{~g})$ & 70.15 & 0.49 & 49.40 & 0.89 \\
\hline Total of MUFA (g/100 g) & 23.37 & 0.83 & 39.58 & 0.90 \\
\hline Total of PUFA $(\mathrm{g} / 100 \mathrm{~g})$ & 2.65 & 0.27 & 9.52 & 0.29 \\
\hline Omega-3 fatty acids (g/100 g) & 0.40 & 0.10 & 0.21 & 0.03 \\
\hline Omega- 6 fatty acids (g/100 g) & 2.17 & 0.29 & 9.31 & 0.26 \\
\hline Trans fatty acids $(\mathrm{g} / 100 \mathrm{~g})$ & 2.66 & 0.07 & 0.27 & 0.06 \\
\hline Short chain fatty acids $(\mathrm{g} / 100 \mathrm{~g})$ & 6.19 & 0.39 & 0.20 & 0.09 \\
\hline Medium chain fatty acids (g/100 g) & 8.30 & 0.43 & 0.53 & 0.17 \\
\hline Long chain fatty acids $(\mathrm{g} / 100 \mathrm{~g})$ & 82.17 & 0.81 & 98.04 & 1.62 \\
\hline Cholesterol (mg/100 g) & 421 & 21 & 49 & 12 \\
\hline
\end{tabular}

In these aspects, the chain length is also an influencing factor - the longer the chain, the more difficult it is to be solubilised in the intestine (RAMíREZ et al., 2001). Due to the palm fat in our sour cream analogue samples, the majority (98\%) of the fatty acids have long chain, the medium and short chain fatty acids are possibly derived from the minor amount of milkfat that comes from the skimmed milk base (Table 4). Furthermore, many studies presented that the short and medium chain saturated fatty acids in milkfat have positive effects on human health (e.g. butyric acid is an anticarcinogen, caprylic, capric, and lauric acids have antiviral activities, etc.), also only three of the twelve major SAFAs of milkfat (lauric, myristic, and palmitic acids) may be involved in raising the cholesterol level of plasma (EBRINGER et al., 2008).

Sour creams contain less omega- 6 and more omega- 3 acids than sour cream analogues, however, in both product categories omega- 6 fatty acids are predominant compared to omega-3 fatty acids (Table 5), and their ratio is far from the ideal 4:1. In modern diets, the consumption of omega- 6 rich fats is too excessive, which increases the risks of CVD, autoimmune diseases, and even cancer (EBRINGER et al., 2008). In case of dairy and dairy analogue products, this issue could be solved by blending omega-3 rich oils (for example canola oil, flaxseed oil) to the products, while appropriate feeding could also contribute to a better balance (ALIZADEH et al., 2017).

Isomerism is another important question regarding unsaturated fatty acids: fat content of sour cream samples consisted of more than $2 \%$ of trans fatty acids as milkfat naturally contains rTFA. In sour cream analogues, TFA ratio is below $0.5 \%$. This amount is very likely originated from the milk base, since palm fat does not require hydrogenation for milkfat replacement. This is confirmed by the fact that elaidic acid, the presence of which is one of the main signs of hydrogenation, was found in the analogues below the detection level.

As discussed in the introduction, there is no evidence that rTFA is as harmful as iTFA. In legislation, many countries made effort to differentiate rTFA and iTFA, and set up limitations only for the artificial trans fatty acids (ZUCHOWSKA-GRZYWACZ \& KowALSKA, 2019).

Low cholesterol content could be listed as one of the advantages of sour cream analogue consumption as cholesterol in the analogue is only one-eighth of the amount measured in sour cream (Table 5). This amount is likely derived from the skimmed milk base, since 
vegetable fats contain negligible amounts of cholesterol (Sun et al., 2015). In the light of the average daily intake of cholesterol (approx. 260-290 mg/day) (Su et al., 2015) and the recommended level (lower than 200-300 mg/day) (KANTER et al., 2012), substituting ordinary sour cream with analogue could be beneficial for restraining cholesterol intake.

\section{Conclusions}

Our study provides gap-filling information on the comparison of a dairy product and its dairy analogue regarding their nutritional aspects. According to our findings, no significant differences could be found between sour cream and sour cream analogues in protein, lactose, fat, and lactic acid bacteria contents. However, analysis of the composition of fat content has proven that analogue products contained less saturated fatty acids and cholesterol and more mono- and polyunsaturated fatty acids. Sour cream analogue products contain significantly less trans fatty acids, nevertheless, it should be noted rTFAs are differentiated from iTFAs by law in many countries, and their ratio in food products is not limited. Although these characteristics suggest that people in risk of CHD could substitute sour cream consumption with analogues, the digestibility of the two products in terms of carbon chain length of the fatty acids might be different. Although, none of the products contain omega- 6 and omega- 3 fatty acids in the ideal balance, sour creams could deliver a ratio of 5.43:1, while analogue samples contain these components in a 44.33:1 ratio.

It should be taken into account that producers are stressed to consider using other fats than palm fat for dairy analogues due to the demand for improved fatty acid composition and sustainability issues (e.g. avoiding tropical oils). Fortification of dairy analogues with vitamins, minerals, or probiotics could be a way for progression as well.

Overall, we can conclude that sour cream analogues, based on their nutritional values, can serve as an alternative product of sour cream, especially when consumed in larger quantities. In the future, more health related innovations are expected in the field of dairy analogues, but the exact role of this product category in the human diet should be outlined by further clinical research, which is currently scarce.

The authors would like to thank the contribution of the NFCSO, especially the Food Chain Safety Laboratory Directorate concerning laboratory investigations, and the methodological guidance of the colleagues of the Doctoral School of Food Sciences, Szent István University.

\section{References}

Alizadeh, A., Ehsani, M.R. \& Rofehgarinejad, L. (2017): Fatty acid profile and cholesterol content of ghezel sheep milk during lactation period. Acta Alimentaria, 46, 457-463.

Codex Alimentarius Hungaricus (2014): 1-3/51-1 elöirás. Tejtermékek. (No. 1-3/51-1 regulation. Dairy products).

Dawczynski, C. \& LoRkowski, S. (2016): Trans-fatty acids and cardiovascular risk: Does origin matter? Expert Rev. Cardiovasc. Ther., 14(9), 1001-1005.

Dunmire, D.L. \& Oтto, S.E. (1979): High pressure liquid chromatographic determination of sugars in various food products. J. AOAC, 62(1), 176-185.

Ebringer, L., FerenČík, M. \& KrajČOviČ, J. (2008): Beneficial health effects of milk and fermented dairy products - Review. Folia Microbiol., 53(5), 378-394. 
EN ISO (2000): Chapter 5. Animal and vegetable fats and oils. Preparation of methyl esters of fatty acids (EN ISO 5509:2000)

EN ISO (2002): Animal and vegetable fats and oils. Determination of the content of trans fatty acid isomers of vegetable fats and oils. Gas chromatographic method. (EN ISO 15304:2002)

EN ISO (2014): Determination of individual and total sterols contents. Gas chromatographic method. Part 1: Animal and vegetable fats and oils. (EN ISO 12228-1:2014)

FAo/Who Food STANDARds (2019): Dairy products and analogues, excluding products of category 02.0 (01.0) Codex Alimentarius.

Fernandez, M.L. (2012): Rethinking dietary cholesterol. Curr. Opin. Clin. Nutr., 15(2), 117-121.

Haisman, D. (2011): Imitation dairy products. -in: FuQuaY, J.W. (Ed.) Encyclopedia of Dairy Sciences: $2^{\text {nd }} \mathrm{ed}$., pp. 913-916. Elsevier Ltd.

IBM CORP. (2015): SPSS Statistics for Windows (No. 23). IBM Corp.

ISO (1992): Animal and vegetable fats and oils. Analysis by gas chromatography of methyl esters of fatty acids. (ISO 5508:1992)

ISO (2005): Microbiology of food and animal feeding stuffs. Horizontal method for the enumeration of mesophilic lactic acid bacteria. Colony-count technique at $30^{\circ} \mathrm{C}$. (ISO 15214:2005)

Kanter, M.M., Kris-Etherton, P.M., Fernandez, M.L., Vickers, K.C. \& Katz, D. L. (2012): Exploring the factors that affect blood cholesterol and heart disease risk: is dietary cholesterol as bad for you as history leads us to believe? Adv. Nutr., 3(5), 711-717.

Krupa, H., Atanu, H.J. \& Patel, H.G. (2011): Synergy of dairy with non-dairy Ingredients or product: A review. AJFS, 5(16), 817-832.

McNamara, D.J. (2010): Palm oil and health: A case of manipulated perception and misuse of science. J. Am. Coll. Nutr., 29, 240S-244S.

McNamara, D.J. (2014): Dietary cholesterol, heart disease risk and cognitive dissonance. P. Nutr. Soc., 73(2), $161-166$.

MSZ (1984): Tejszín, savanyú tej-, tejszinkészitmények és ízesített tejtermékek zsirtartalmának meghatározása. (Determination of fat content of cream, fermented milk and cream products and flavoured milk products) MSZ 9602:1984 Chapter 1

MSZ (1987): Élelmiszerek és élvezeti cikkek nitrogéntartalmának meghatározása Kjeldahl-féle módszerrel (Food products. Determination of nitrogen content by Kjeldahl method) MSZ 1385:1987

NozNICK, P.P., ATAMER, Z. \& HinRICHs, J. (2015): Dairy products, imitation. -in Ullmann's Encyclopedia of Industrial Chemistry. Wiley-VCH Verlag GmbH \& Co. KGaA. https://doi.org/10.1002/14356007.a08_239.pub2 (last accessed 1 July 2020)

Pinto, V.R.A., Melo, L.F., Balbino, D.F., Novaes, J.F. De, Negrete, M.C. \& Sousa, T.D. De. (2016): The evaluation of consumer behavior influence on the buying process of dairy products in Minas Gerais state, Brazil. J. Food Nutr. Res., 4(1), 51-59.

Ramírez, M., Amate, L. \& GiL, A. (2001): Absorption and distribution of dietary fatty acids from different sources. Early Hum. Dev., 65(Suppl. 2), 95-101.

Su, C., JiA, X., WANG, Z., WANG, H. \& ZHANG, B. (2015): Trends in dietary cholesterol intake among Chinese adults: A longitudinal study from the China health and nutrition survey, 1991-2011. BMJ Open, 5(6):e007532.

Sun, Y., Neelakantan, N., Wu, Y., Lote-Oke, R., Pan, A. \& M Van Dam, R. (2015): Palm oil consumption increases LDL cholesterol compared with vegetable oils low in saturated fat in a meta-analysis of clinical trials. J. Nutr., $145,1549-1558$

Szakály, S. (ED.) (2001): Tejgazdaságtan (Dairy economics). Dinasztia Kiadó, Budapest. pp. 211-216.

WHO (2018): Healthy diet. Key facts. Fact Sheets. https://www.who.int/news-room/fact-sheets/detail/healthy-diet (last accessed: 1 July 2020)

ZuchowsKa-Grzywacz, M. \& Kowalska, M. (2019): Trans fatty acids in food - Current legal regulations as protections for consumers and food manufacturers. Acta Alimentaria, 48, 105-114.

Open Access statement. This is an open-access article distributed under the terms of the Creative Commons Attribution 4.0 International License (https://creativecommons.org/licenses/by/4.0/), which permits unrestricted use, distribution, and reproduction in any medium, provided the original author and source are credited, a link to the CC License is provided, and changes - if any - are indicated. (SID_1) 